\title{
EL PINTOR JUAN DE MIRANDA (1723-1805): REDESCUBRIMIENTOS Y NUEVAS ATRIBUCIONES
}

\author{
Juan Alejandro Lorenzo Lima*
}

\section{RESUMEN}

En este artículo se dan a conocer varias obras que pudo realizar el pintor Juan de Miranda (1723-1805), conservadas en templos y domicilios de la isla de Tenerife. Refiere también lo conocido sobre dos lienzos que otros investigadores vincularon años atrás con su producción, cuyo redescubrimiento casual en Burgos y Santa Clara (Cuba) permite establecer lecturas o análisis interpretativos más completos porque insisten en la notoriedad de ciertas iconografías, los modelos artísticos, la dependencia creativa respecto al grabado y el vínculo con la religiosidad del siglo XVIII.

Palabras Clave: Juan de Miranda, pintura, siglo xvin, Canarias, grabado, religiosidad ilustrada.

THE PAINTER JUAN DE MIRANDA (1723-1805):

REDISCOVERIES AND NEW ATTRIBUTIONS

\section{Abstract}

In this essay we present several works that artist Juan de Miranda (1723-1805) could paint, preserved in churches and homes on the island of Tenerife. It also refers to the analysis carried out about two more paintings that other researchers had related to his pictorial production, whose casual rediscovery in Burgos and Santa Clara (Cuba) allows for more comprehensive interpretative readings or analyzes because they affect iconographic themes, artistic models, creative dependence on engraving and its relationship with the religious forms of the Enlightenment.

KeYwords: Juan de Miranda, painting, $18^{\text {th }}$ century, Canary Islands, engraving, religiousness of the Enlightenment. 
A la memoria de A. Sebastián Hernández Gutiérrez, profesor, investigador e intérprete del patrimonio villero

La producción de cualquier artista está sujeta a lecturas y visiones contrapuestas, hasta el punto de que su estudio clarifica el sentido que tenemos sobre aspectos vinculados con el estilo de un momento concreto, la originalidad manifestada por obras de diverso alcance y, sobre todo, el medio en que se inscribe la labor de dichos maestros y su mayor o menor vínculo con él. El paso del tiempo no ayuda a veces en esa tarea, sino que, al contrario, los cambios de gusto y la superación de etapas históricas impiden advertir tales circunstancias con una claridad meridiana. A nadie escapa que la contemporaneidad y los juicios manifestados en épocas pasadas lastran a menudo un análisis objetivo de muchos autores, de modo que tal coyuntura, susceptible siempre de interpretaciones o cambios de parecer, exige un esfuerzo mayor por parte de historiadores y críticos de arte. Lo acontecido por último en torno a Bartolomé Esteban Murillo (1617-1682) es un ejemplo claro de esa dinámica, porque, tras décadas con una historiografía variable e irregular, el cuarto centenario de su nacimiento propició una renovación de los estudios e investigaciones que había motivado desde el siglo xix. Un ensayo muy revelador acerca de la valía de sus imágenes, lecturas contextuales, la edición de documentos, toda clase de exposiciones y el congreso internacional de 2018 han contribuido a fijar una interpretación diferente del pintor, revelándonos a un Murillo mucho más comprometido con el arte de su tiempo y con las exigencias que una época de crisis como la que le tocó vivir junto a discípulos y continuadores ${ }^{1}$.

Tal vez sea el momento idóneo para ampliar horizontes y sugerir nuevas propuestas de contextualización en otros casos, ya que, obviando las diferencias que imponen de modo forzoso la distancia y los tiempos, dicha dinámica se revela como pauta o modelo a seguir. La recuperación de Murillo sirve de estímulo a la hora de afrontar el análisis de artistas que esperan una revisión semejante, al margen de que sean conocidos o no en su entorno y ámbito de influencia. Entre los grandes maestros de nuestro país esa dinámica es común por una larga tradición historiográfica $^{2}$, pero en los entornos secundarios y periféricos el panorama resulta mucho más difuso. En ellos el afán localista se presenta como un problema que impide establecer lecturas ambiciosas, de modo que, si no llegan a superarse los relatos pre-

* Doctor en Historia del Arte. Docente de la Consejería de Educación y Universidades, Gobierno de Canarias. http://orcid.org/0000-0001-9016-2529, https://independentresearcher.academia.edu/JuanAlejandroLorenzoLima.

${ }^{1}$ La bibliografía aparecida al respecto es amplia y muy diversa, pero deben destacarse al menos las contribuciones de Navarrete Prieto, Benito (2017): Murillo y las metáforas de la imagen. Madrid, Ediciones Cátedra; Hereza, Pablo (2017): Corpus Murillo: biografía y documentos. Sevilla, Ayuntamiento de Sevilla; Cano Ribero, Ignacio y Muñoz Rubio, María del Valme (coord.) (2018): Murillo. IV centenario. Sevilla, Junta de Andalucía; y Navarrete Prieto, Benito (dir.) (2019): Murillo ante su IV centenario. Perspectivas historiográficas y culturales. Sevilla, Universidad de Sevilla.

2 Tal y como explica Portús, Javier (2012): El concepto de pintura española. Historia de un problema. Madrid, Ediciones Verbum. 
vios y las argumentaciones de tipo positivista, apenas avanzaríamos en la consideración de dichos artífices y de la obra que nos legaron bajo condicionantes sujetos a una interpretación múltiple.

Gracias a publicaciones anteriores destacamos ya la singularidad de Juan Ventura de Miranda y Cejas (1723-1805) en ese sentido, puesto que su pintura aportó novedades en cuestiones de fondo y forma para el discurrir de las artes en el Archipiélago. Además, últimos estudios insisten en la idea de que su trayectoria vital, tan cambiante como el mismo siglo XVIII donde se inscribe, guarda relación con transformaciones producidas lejos del Archipiélago. Un episodio crucial como el encarcelamiento en Orán después de $1758^{3}$, la participación frustrada en el concurso de pintura convocado por la Academia de San Fernando en $1760^{4}$ y su posterior viaje por tierras peninsulares otorgan singularidad a Miranda frente al resto de pintores que trabajaban en Canarias desde época precedente, de modo que el bagaje reunido entonces y su evolución posterior lo convierten en un pintor de interés por la asimilación de cuantas novedades procuraba el arte académico en aquel tiempo ${ }^{5}$. No obstante, esa realidad esconde otras cuestiones que conviene investigar y replantear mejor, tanto en lo concerniente a su derrotero vital como profesional.

Son muchos los datos biográficos que desconocemos todavía, pero diversos testimonios prueban que durante la década de 1790 el propio artista quiso enmendar los errores del pasado y demostrar la notoriedad de los ascendientes que tuvo por ambas ramas de la familia. No extraña que probara entonces su «clara y limpia generación» y que, en sintonía con el ideario de la Ilustración, ello le brindase la posibilidad de legitimar un oficio que no despreciaba por el componente manual. Al contrario, como había hecho ya José Rodríguez de la Oliva (1695-1777), reivindicó siempre la liberalidad de su trabajo con el pincel y el aporte intelectual que subyacía tras él ${ }^{6}$. Con esta circunstancia se disipan las dudas en torno a un creador que los biógrafos del siglo XIX describieron a menudo como errante y melancólico, por lo que, de acuerdo a esa idea, su vida sería reflejo de unas condiciones sociales que no eludió durante el tiempo de residencia en Fuerteventura, Gran Canaria, Lanzarote y Tenerife. En ese sentido sabemos que la personalidad y el arte de Miranda difieren del trasfondo piadoso que Agustín Millares Torres les atribuía en un primero momento ${ }^{7}$, pero dicha coyuntura no es del todo válida para comprender lo

${ }^{3}$ SuÁrez Grimón, Vicente (2008): «El envío del pintor Juan de Miranda al presidio de Orán: un reflejo de la crisis de la Audiencia de Canarias en el siglo XviII", Anuario de Estudios Atlánticos, 54, t. II, pp. 265-296.

${ }^{4}$ Lorenzo Lima, Juan Alejandro (2011): «Juan de Miranda en la Academia. El artista y su participación en el concurso de pintura de 1760", Estudios Canarios. Anuario del Instituto de Estudios Canarios, LV, pp. 173-206.

${ }^{5}$ Lorenzo Lima, Juan Alejandro (2011): Juan de Miranda. Reverso de un autorretrato. Islas Canarias, Gaviño de Franchy Editores, con bibliografía previa al respecto.

${ }^{6}$ Rodríguez González, Margarita (1994): Juan de Miranda [catálogo de la exposición homónima]. Santa Cruz de Tenerife, Caja General de Ahorros de Canarias, pp. 23-24.

7 Millares Torres, Agustín (1982): "Juan de Miranda», Biografía de canarios célebres. Las Palmas de Gran Canaria, Ediciones Edirca, t. I, pp. 197-201. 
que sucedió durante tantos años de trabajo frente al lienzo. Décadas después, María Rosa Alonso, Pedro Tarquis y Sebastián Padrón Acosta, entre otros muchos, ayudaron a perpetuar la imagen de Juan de Miranda como la de un autor prolífico y de pasado oscuro e intrigante por algunos acontecimientos ${ }^{8}$.

Debería recordarse que gran parte de las obras del pintor cuenta con una cronología tardía, porque, salvo las pocas documentadas o firmadas antes de que lo trasladaran a Orán, el resto empieza a fecharse y contextualizarse después de 1773. También era conocido que se mantuvo en activo hasta que murió en 1805, de forma que su efectividad habría que constreñirla a las casi cuatro décadas que anteceden al cambio de siglo?. No es un periodo breve y el volumen de pinturas constatadas o atribuibles que vamos conociendo se antoja insuficiente para un maestro que tuvo dedicación continua al arte, si bien varios documentos informan acerca de su vínculo con proyectos que promovieron la pesca de alcance o mayor calado antes de finalizar la centuria. Hay que recurrir a ese otro hecho y al estatus de notable que se le dio en ocasiones para conocer mejor a un artífice que abogó siempre por la regeneración de las artes, aunque en 1760 advertía ya que era natural de «una tierra [...] sin luz alguna en los primores del arte» ${ }^{10}$.

Partiendo de lo argumentado como propuesta de análisis, este artículo reúne impresiones y avances en torno a la investigación de un autor complejo como Miranda, que complementan lo recogido años antes en otro que le dedicamos para sintetizar últimas noticias y novedades ${ }^{11}$. Ahora, sin el afán compilador como única meta, lo que se presenta en los epígrafes siguientes son aportes y posibles líneas de trabajo con el fin de esclarecer un poco más la producción del artista. Con ello aspiramos a replantear lo ya conocido y ser partícipes de nuevas lecturas en clave contextual, sin descuidar, claro está, localizaciones, formatos, usos y temáticas de algunas obras que conciernen de diverso modo a la pintura que practicaron otros creadores del siglo XVIII.

\section{REDESCUBRIMIENTOS FUERA DE CANARIAS Y CONSIDERACIONES DE ESTILO}

Al igual que sucede con maestros similares o de la periferia española, uno de los problemas que implica el estudio de la producción mirandesca es la dispersión en lo geográfico; y si a ello unimos el desconocimiento que se tiene del autor y de su

${ }^{8}$ Un primer balance del alcance historiográfico en Rodríguez GonzÁLez, Margarita (1986): La pintura en Canarias durante el siglo XVIII. Las Palmas de Gran Canaria, Cabildo de Gran Canaria, pp. 294-369, donde se recoge la bibliografía previa.

9 Rodríguez González, Margarita (1990): El pintor Juan de Miranda 1723-1805. Las Palmas de Gran Canaria, Cabildo de Gran Canaria, pp. 25-28.

${ }_{10}$ Archivo de la Real Academia de Bellas Artes de San Fernando, Madrid: Sign. 2-I-4.

${ }^{11}$ Lorenzo Lima, Juan Alejandro (2018): «Varia mirandesca. Atribuciones y últimas novedades sobre la pintura de Juan de Miranda (1723-1805)», Revista de Historia Canaria, 200, pp. 125-139. 
arte lejos de Canarias, resulta comprensible que obras vinculables con él no puedan catalogarse de forma adecuada. De ahí que pinturas donde se refleja su estilo aparezcan bajo otras adscripciones en subastas y publicaciones peninsulares, aunque, cuando ello se produce, la opinión en torno a dichas piezas no es unánime entre historiadores y galeristas. Sucedió lo contrario con una Inmaculada que continúa a la venta en Tarragona ${ }^{12}$ y con una Virgen del Rosario que provenía de Alicante y conocimos en el comercio madrileño a principios de 2017, si bien tiempo después acabó adquiriéndola un coleccionista de Puerto de la $\mathrm{Cruz}^{13}$. Seguir la pista a lienzos suyos fuera de Canarias es complejo y muy dificultoso, pero a veces circunstancias excepcionales ayudan a identificarlos de modo conveniente.

Por eso mismo, gracias a la exposición Visiones de América, que organizó la Caja de Burgos en 2018, localizamos una Adoración de los Magos que ya se había vinculado con el estilo de Miranda y era conocida por una fotografía de poca cali$\mathrm{dad}^{14}$. Figuró en la muestra como obra novohispana, datándola los comisarios y sus propietarios en el siglo XVIII ${ }^{15}$. Aunque no hay constancia de ese hecho por ventas posteriores y el hermetismo surgido a su alrededor, debe tratarse de la misma pintura de autor anónimo que la casa Durán de Sevilla subastó en 1995, puesto que la similitud del formato y la coincidencia de detalles no dejan lugar a la duda. Con todo, la negativa a prescindir de la catalogación americana resulta sintomática del interés que el arte colonial despierta en nuestro país, así como de una confusión habitual entre las creaciones isleñas y otras llegadas del Nuevo Mundo. No es la primera vez que en subastas, publicaciones divulgativas y estudios científicos se da esa coyuntura, hasta el punto de que empieza a ser algo generalizado en el Archipiélago cuando nos enfrentamos a piezas de catalogación dificultosa ${ }^{16}$.

En este caso creemos que se trata de un trabajo estimable de Juan de Miranda, cuya atribución respalda el paralelismo que Díaz Padrón advirtió entre su modelo compositivo y una obra del mismo asunto que conservan los descendientes del conde de la Vega Grande en Las Palmas ${ }^{17}$. A esa comparativa se suma ahora una tercera pintura de la Adoración de los Magos que integra la colección Hernández Calzadilla en Santa Cruz de Tenerife, cuya similitud con las recreaciones de Burgos y

12 Muñız Muñoz, Ángel (2015): «Una posible Inmaculada de Juan de Miranda localizada en Tarragona", Homenaje a la profesora Constanza Negrín Delgado. La Laguna, Instituto de Estudios Canarios, pp. 443-455.

${ }^{13}$ Lorenzo Lima, Juan Alejandro (2018): «Varia mirandesca...», art. cit., pp. 136-139.

${ }^{14}$ Díaz Padrón, Matías (2016): «Juan de Miranda en Sevilla», La Provincia. Diario de Las Palmas, Las Palmas de Gran Canaria, 11/4/2016, p. 54.

15 AA. VV. (2018): Visiones de América. Arte desde el confin del mundo [catálogo de la exposición homónima]. Burgos, Caja de Burgos, pp. 46-47.

16 Sirvan de ejemplo en ese sentido los juicios que emite acertadamente Mesa Martín, José María (2010): «La Inmaculada Concepción de Santa Catalina de Tacoronte y la sudoración milagrosa: la autoría", Vjornadas de investigación y divulgación histórica de Acentejo. Santa Cruz de Tenerife, Ediciones Idea, pp. 49-83.

${ }_{17}$ Díaz Padrón, Matías (1966): «Seis pinturas de Juan de Miranda sobre la infancia de Cristo», Anuario de Estudios Atlánticos, 12, pp. 536-537, fig. 2. 
Gran Canaria es innegable. No obstante, como trataremos luego en relación con un lienzo inédito de Garachico [fig. 6], todas ellas dependen de grabados flamencos de la centuria precedente. Al igual que hizo Miranda otras veces, la caracterización que ofrece del tema deja entrever la cercanía del maestro a los rigores de su tiempo sin eludir pautas prestablecidas para la composición de un motivo tan convencional: desplazamiento de la escena principal al extremo derecho, contextualización con un fondo arquitectónico en ruinas, apertura al paisaje en el otro lateral $y$, sobre todo, un sentido descriptivo de mayor vistosidad para la cabalgata de los magos, donde no faltan detalles que manifiestan la notoriedad de su ejecución pese al formato medio del lienzo $(65 \times 96 \mathrm{~cm})$.

El hallazgo de esta obra es revelador para conocer las cualidades del arte de Miranda durante los años del viaje peninsular, periodo en el que debe inscribirse a partir de ahora. Una comparativa con el cuadro de San Fernando presentado a la Academia en 1760 respalda esa idea, ya que en ambos advertimos un mismo estudio de las formas con cuerpos ligeramente estilizados, el afán de personalizar la composición pese a la deuda con el grabado, las poses diversas que describen los reyes junto a su séquito, el modo de resolver la profundidad con personajes indefinidos al fondo y, muy especialmente, el lujo del que hacen gala los magos con el atuendo y toda clase de adornos suntuarios. En ello podría verse un rasgo orientalizante que caracterizó al arte de Miranda y de otros coetáneos cuando recreaban motivos históricos ${ }^{18}$, pero no es el único detalle a tener en cuenta.

La técnica tan depurada, el estudio de la luz y una paleta armónica tendente a azules, blancos, verdes y grises de fácil combinación ayudan a caracterizar el estilo del artista en un momento clave de su trayectoria, cuando daría acabado a esta obra con un fin y una ubicación que ignoramos por ahora. De ahí la variedad de recursos y soluciones que pueden encontrarse en otras piezas, puesto que durante el periodo peninsular sus lienzos no muestran unos rasgos tan definidos ni la simpleza que caracteriza a muchos realizados tras la vuelta a Canarias. Tal vez por ello sea difícil seguir la pista a creaciones de alcance y significación variables, aun cuando algunas no reflejan tanta disparidad en los temas, las soluciones compositivas y, sobre todo, los modelos o rasgos fisonómicos. Así, al margen de los cuadros ya documentados para el Ayuntamiento de Alicante en 1767, creemos que con el artista podrían vincularse algunas pinturas notables, entre ellas una Inmaculada que perteneció a la colección del coronel Manuel Montesinos (1796-1862) en Valencia, el San Eloy que cubría la hornacina del retablo mayor en la iglesia de San Bartolomé de Murcia y una amplia Coronación de la Virgen que estuvo a la venta en la galería López Aragón de Madrid, cuyos análisis formales no ofrecen tantas dudas por la comparativa ya seńalada con trabajos posteriores ${ }^{19}$. Sin embargo, esa dinámica también es

18 Rincón García, Wilfredo (1998): «Temas orientalistas en la pintura española del siglo XVIII", Actas del I congreso internacional de pintura española del siglo XVIII. Marbella, Centro del Grabado Contemporáneo, pp. 45-52.

19 No entraremos en la exposición de estas cuestiones, abordadas ya en Lorenzo Lima, Juan Alejandro (2011): Juan de Miranda..., op. cit., pp. 60-89. 


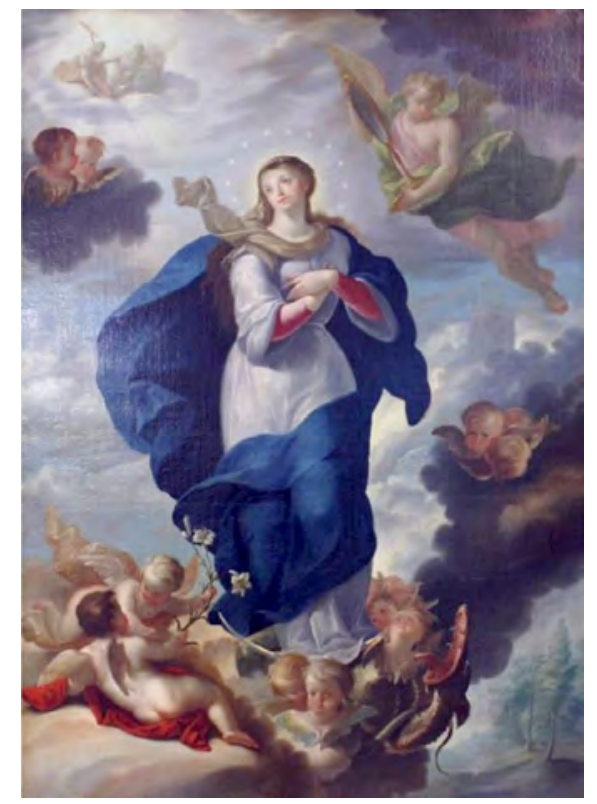

Fig. 1. Atribuido a Juan de Miranda: Inmaculada. Museo de Bellas Artes, Guadalajara.

[Foto: Archivo Museo de Bellas Artes de Guadalajara].

útil para establecer otras propuestas de estudio y advertir rasgos diferenciadores a la hora de concretar personajes o tipos propios.

Con estas pinturas sucede lo mismo que con una Virgen del Rosario que estuvo largo tiempo de Alicante, antes aludida, puesto que lo contemplado en ella no coincide en todos los detalles con realizaciones isleñas o de fecha tardía. La reiteración de modelos tan diversos invita a pensar en que lejos del Archipiélago Miranda definió un estilo distinto al que conocemos y que fue entonces, no en época previa ni al retornar a Tenerife antes de 1773, cuando su lenguaje plástico evolucionó hacia formas que define el academicismo latente en Madrid, Valencia o Sevilla. Además, si nos aproximamos a otros lienzos de ese tiempo que se le pueden atribuir como una Purísima que el Museo de Bellas Artes de Guadalajara no exhibe de modo permanente [fig. 1], a menudo olvidada, queda claro que en aquella época los modos mirandescos asumen fundamentos próximos al bello ideal y a su teorización entre artistas e intelectuales de diverso calado ${ }^{20}$. A nuestro juicio, tal coyuntura explica los planteamientos seguidos por el maestro y su vínculo con un entorno que propi-

${ }^{20}$ Rodríguez González, Margarita (1994): Juan de Miranda..., op. cit., p. 23. La pintura de Guadalajara fue citada por RodríGuez GonzÁlez, Margarita (1986): La pintura en Cana- 
ció el avance y la regeneración de las artes, ya que, precisamente, ese mismo medio justificaría la disparidad de algunos trabajos que han ido publicándose por último.

Los rasgos que manifiesta la obra de Guadalajara no se advierten en dos versiones más de la Inmaculada que pudo pintar antes de 1773 y provienen de Tarragona y Valencia, siendo la última el ejemplar que perteneció al coronel Montesinos. En ellas tienen cabida recursos que el artista repitió luego en creaciones del Archipiélago, tendentes por lo general a un claro alargamiento de los cuerpos, al contraste entre blancos y azules intensos para definir el atuendo mariano, a un prototipo femenino que es reconocible gracias a sus componentes esenciales, al adorno con ángeles de relación armónica entre sí y, sobre todo, a un acabado no tan preciso en lo técnico, que revela ya procedimientos comunes en la plástica posterior de Miranda. Además, lejos de las gamas frías que ofrecen a menudo muchas realizaciones suyas, en ambas predomina un colorido diferente e intenso, que tiende a definir el fondo de los celajes con bermellones y naranjas ${ }^{21}$.

De lo que se trata es de no enjuiciar las obras del periodo peninsular con una perspectiva limitada a los modelos isleños, sino que, al contrario, su estudio debe plantearse con un punto de vista amplio y diverso, no cuestionando el afán comparativo. Sin olvidar los vínculos o débitos formales que proponen algunas atribuciones, hay que partir de un convencimiento claro: el artista se manifiesta entonces como un creador heterogéneo, abierto al influjo de los lugares donde trabaja en la búsqueda de un estilo que no llega a consolidar ni personalizar del todo. De ahí las diferencias que se advierten a veces en la caracterización de los rostros y en los propios componentes de sus lienzos, aunque, si establecemos una relación detenida entre ellos, muestran también paralelismos en lo concerniente a atributos, estudios gestuales, ambientaciones y no pocos ángeles que forman parte de los fondos celestes con hábil recreación y colorido. Habrá, pues, que reconocer en esas cualidades a un maestro cambiante y proclive a la modernidad, que buscaba el reconocimiento negado en la tierra de origen por su conducta ${ }^{22}$.

A la etapa peninsular o a los primeros ańos de actividad en las Islas podría corresponder una pintura que redescubrimos al visitar el Museo de Artes Decorativas de Santa Clara, en la isla de Cuba [fig. 2]. Se trata de la Inmaculada que Díaz Padrón atribuyó a Miranda en 1977 y conocíamos tan solo por una vieja fotografía en blanco y negro, de modo que su paradero era un enigma hasta ahora ${ }^{23}$. Gracias a la ficha de inventario disponible en el centro comprobamos que se trata de la pieza

rias durante el siglo XVIII, p. 317 a partir de un comentario previo de Hernández Perera, aunque pudimos estudiarla en Lorenzo Lima, Juan Alejandro (2011): Juan de Miranda..., op. cit., pp. 79-81.

${ }^{21}$ Lorenzo Lima, Juan Alejandro (2011): Juan de Miranda..., op. cit., pp. 73-79; MuÑız Muñoz, Ángel (2015): «Una posible...», pp. 443-455.

22 Así lo advertimos a raíz de los juicios que motivó su encarcelamiento en Las Palmas y las peticiones que hizo a la Audiencia de forma reiterada para no ser llevado a Orán junto a otros reos. Cfr. SuÁrez Grimón, Vicente (2008): «El envío...», art. cit., t. II, pp. 265-296.

${ }^{23}$ Díaz Padrón, Matías (1977-1979): «Una Inmaculada de Juan de Miranda en La Habana», El Museo Canario, xxxvIII-XL, pp. 135-137. 


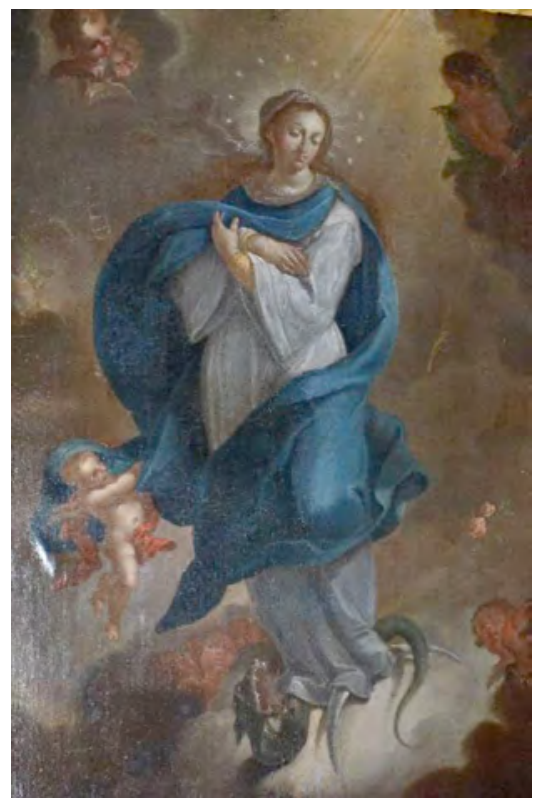

Fig. 2. Atribuido a Juan de Miranda: Inmaculada. Museo de Artes Decorativas, Santa Clara (Cuba). [Foto: Juan Alejandro Lorenzo].

publicada entonces, puesto que figura allí como obra de atribución dudosa al pintor Juan de Roelas (...1561-1608). Esa autoría es la misma que tuvo décadas antes y resulta insostenible por cuestiones de técnica y estilo, tal y como puede advertirse a simple vista. Lo poco que sabemos de ella se limita a su participación en la Exposición Nacional de Artes Plásticas celebrada en La Habana durante 1940, bajo el patrocinio de la Universidad Nacional y la ya extinta Corporación de Turismo Nacional. Así consta en un papel adherido al reverso del cuadro y en el catálogo de la muestra, donde los organizadores informaron que en aquel momento era propiedad de Juan Tomás Díaz²

Dicho personaje fue un inversor y coleccionista de arte antiguo que tuvo residencia en La Habana, algo que no ayuda a esclarecer el origen de la pintura. Es probable que el mismo Díaz la adquiriese en la isla o que, incuso, la importase desde España, ya que otros bienes de su colección llegaron a Cuba después de que visitara nuestro país a raíz de las exposiciones internacionales celebradas en 1929. Años más tarde el lienzo era propiedad de Dolores Quesada, vecina de Santa Clara

${ }^{24}$ AA.VV. (1940): Exposición de Arte. Escuelas europeas [catálogo de la exposición homónima]. La Habana, Instituto Nacional de Artes Plásticas, p. 18, n. ${ }^{\circ} 18$. 
que reuniría un elevado número de antigüedades en el domicilio donde vivió junto a su familia en dicha localidad. No fue comprado por las autoridades de la región de Santa Clara hasta abril de 1985, por lo que figura expuesto como parte de la colección permanente del museo desde su apertura al público en diciembre de $1987^{25}$.

Al margen de un origen tan incierto, la obra resulta de interés por varios motivos. Su existencia en Cuba deja abierta la posibilidad de que estuviera allí en el siglo XVIII, tal vez, como dedujo Díaz Padrón, porque es producto de un envío o una importación producida en tiempos del pintor. Sin embargo, esa idea no puede confirmarse atendiendo a la trayectoria de sus antiguos propietarios y a los vínculos que unieron a tantos isleños con el Caribe durante las centurias del Antiguo Régimen. Cuba fue un territorio de emigración constante para los canarios a lo largo del Setecientos y ello, al margen de otras lecturas posibles, confirma el interés que sus creadores tuvieron por conocer la entonces añorada isla de Cuba o de La Habana. José Luján Pérez (1756-1815) debió viajar hasta La Habana antes de $1787^{26}$, pero, en el caso de Miranda, el periplo americano que supone Rodríguez González no se ha documentado aún y resulta incompatible con lo que vamos sabiendo de su trayectoria antes de 1770. Además, la Inmaculada del Museo Franz Mayer de México que se creía suya es en realidad una obra del pintor homónimo que trabajó allí a principios del Setecientos ${ }^{27}$ y, hasta donde conocemos, no hay noticias ni pistas fiables acerca de los cuadros que pudo ajustar para la catedral de Campeche. Millares Torres alude a ellos y deja entrever que su ejecución resultaría probable antes de 1800 , porque, entre otras razones, esa ciudad y su puerto fueron un punto clave para la emigración de isleños a lo largo del siglo XviıI ${ }^{28}$.

Más allá de esos aspectos dudosos, la Inmaculada de Santa Clara se revela como una contribución importante para el estudio de la producción mirandesca. Sus cualidades fueron valoradas y estudiadas anteriormente, ya que, a partir de la fotografía disponible, podían establecerse paralelismos con otras figuraciones del mismo tema existentes en Tenerife ${ }^{29}$. No obstante, el interés es mayor al advertir que la composición y el modelo mariano plasmado en ella remiten a prototipos difundidos por la estampa, la escultura y la pintura contemporánea, resultando próxima al estilo de maestros activos en ciudades del Levante que Miranda visitó antes de 1770. Sirvan de ejemplo en ese sentido algunas láminas que los grabadores Ignasi Vals (1726-1764) y Vicente Galcerán (1726-1788) dedicaron a la Inmaculada, aun-

${ }^{25}$ Archivo del Museo de Artes Decorativas de Santa Clara, Cuba: Sección Inventario. Registro de pinturas. Carpeta 2, fichas sueltas sin clasificar.

26 Así lo recogió en un primer momento Martínez de Escobar, Bartolomé (1850): Memoria de Don José Luja y Pérez, escultor, arquitecto y maestro de dibujo de la Academia de esta ciudad [Las Palmas de Gran Canaria] e individuo de su sociedad Económica de Amigos del Pais. Santa Cruz de Tenerife, Imprenta Isleńa, p. 17.

27 Así lo hizo ver, entre otros, Amador Marrero, Pablo F. (2006): «Dos cobres del pintor novohispano Antonio Sánchez en Canarias», Anales del Instituto de Investigaciones Estéricas, 88, pp. 206-207.

${ }^{28}$ Millares Torres, Agustín (1982): «Juan de Miranda», op. cit., p. 199.

29 Rodríguez González, Margarita (1986): La pintura..., op. cit., p. 342. 


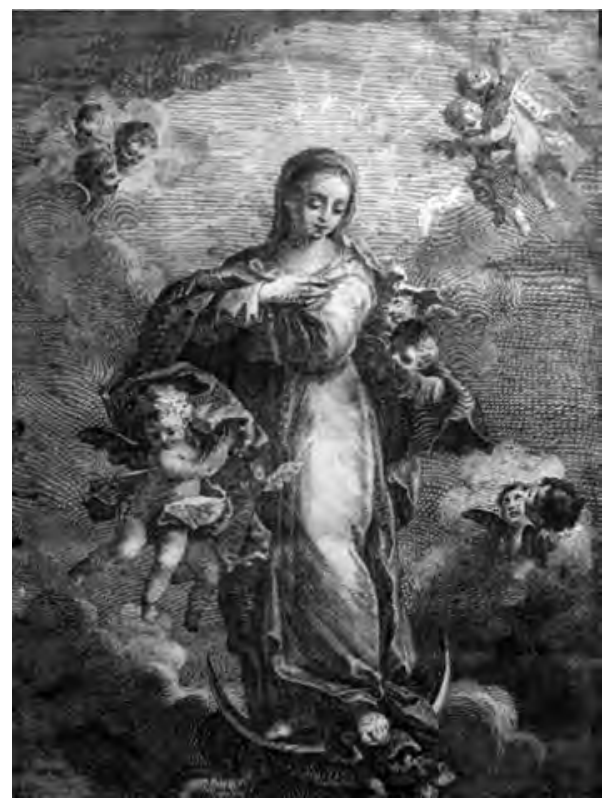

Fig. 3. Anónimo: Inmaculada. Colección particular, Santa Cruz de Tenerife. [Foto: Ángel Muñiz].

que tal paralelismo habría que extenderlo a creaciones coetáneas bajo un sentido amplio y diverso. En ese sentido, Muñiz Muñoz nos sugiere el vínculo con una estampa dieciochesca de autor anónimo que pudo conocer el artista, a buen seguro de origen madrileño o valenciano [fig. 3].

A pesar de ese u otro débito impreciso por ahora, los rasgos inconfundibles de su arte afloran en el alargamiento que describe el cuerpo de la Virgen, el ligero contraposto, la aureola de estrellas y ráfagas que irradia de su cabeza, la ambientación procurada al celaje con atributos de la letanía lauretana, la recreación de la serpiente como símbolo del mal, los prototipos angélicos que se prestan a fácil comparativa con creaciones posteriores y, muy especialmente, la paleta con una gama habitual de grises, azules y blancos, contrarrestada tan solo con toques de rojo en el paño que cubre a un angelito y con el amarillo que muestran las mangas del traje mariano. Esos convencionalismos no son incompatibles con novedades advertidas en el apartado técnico y la calidad manifestada en algunos detalles, si bien el lienzo da la impresión de que fue intervenido antes de su ingreso en el museo y tal vez recortado en los extremos ${ }^{30}$.

${ }^{30}$ En la actualidad mide $86,5 \times 63,5 \mathrm{~cm}$. Agradecemos las indicaciones que nos brindó el conservador del museo Jesús Llorens León a la hora de conocer y estudiar in situ la obra. 
Hay dos elementos que singularizan a esta pieza en el amplio repertorio de Inmaculadas mirandescas: uno tiene que ver con la configuración del atuendo de la Virgen, cuyo manto queda recogido al cuello con un broche que lo une a una sobretúnica blanca de suave plegado que esconde a los pies; y el otro guarda relación con el dinamismo que se infunde a ese tejido en concreto, cuyo movimiento acentúa el lenguaje gestual del personaje mariano por cruzar los brazos a la altura del pecho alzando los codos. Esos detalles y cierta originalidad en los rasgos del rostro, algo intervenidos pero distinguibles fácilmente a pesar de unos párpados más abultados que de costumbre, le infunden novedad en el grupo de obras sobre este tema que afrontó el maestro. De ahí que pueda ponerse en relación con algunas piezas ya conocidas, aunque curiosamente revela un paralelismo mayor con otra Inmaculada que fue vendida por Abalarte Subastas en febrero de 2017 y corresponde con un trabajo de menor calidad, a buen seguro realizado por un seguidor o discípulo que conoció sus creaciones ${ }^{31}$.

\section{HACIA UNA INTERPRETACIÓN MÚLTIPLE DE LA PINTURA RELIGIOSA}

Las investigaciones previas de Rodríguez González y últimos estudios han demostrado que Miranda fue algo más que un autor devocional o de temática piadosa, puesto que su dedicación a géneros dispares como la pintura de historia, la alegoría y el retrato es un aval a la hora de probar dicha circunstancia. Desde ese punto de vista, el estudio de las composiciones religiosas sirve para aproximarnos a una realidad paralela y extraer de ellas conclusiones que trascienden al fin o sentimiento devoto. La contextualización prevista a veces, los motivos secundarios, el sentido de la narración y hasta la propia definición de los temas nos previenen sobre la habilidad del artífice a la hora de articular sus composiciones, al margen de que recurriera a estampas o a toda clase de referentes figurativos para darles forma. Esa dinámica es común entre muchos maestros del siglo XviII, pero, vista con una perspectiva amplia e integradora, resulta de mayor atractivo para un autor periférico como Miranda.

Creaciones suyas alientan una consideración múltiple de la obra resultante, puesto que a veces aúnan varios géneros y el fin no se circunscribe a la piedad popular, tanto en su manifestación pública como colectiva. En un ensayo anterior señalamos la originalidad de piezas estimables como la Alegoría de la Inmaculada y España que firmó en 1778 (conservada en la parroquia matriz de Santa Cruz de Tenerife) o la Purísima de Carlos III (ahora en colección particular de Barcelona), cuya existencia confirma que el ideario ilustrado renovó la tradición figurativa para convertirla en un medio válido de instrucción si el maestro valora y entiende lo que plasma el

${ }^{31}$ Se conserva desde entonces en un domicilio particular de Santa Cruz de Tenerife. Lorenzo Lima, Juan Alejandro (2011): «Varia mirandesca...», art. cit., pp. 135-136. 
lienzo, asume los convencionalismos del tiempo que le toca vivir y, sobre todo, dispone de apuntes o dibujos con los que componer evitando una copia literal. En ese sentido, gracias a la contextualización de dichas pinturas y al conocimiento de las fuentes grabadas o literarias que pudo manejar, deducimos que Juan de Miranda fue un intérprete hábil a la hora de recrear y abocetar con motivos que aportaba la estampa coetánea, no reproduciéndolos fielmente en muchos $\operatorname{casos}^{32}$.

Su valía no se limita a ese aspecto, porque, si atendemos a los análisis que posibilitan últimos hallazgos y atribuciones, se constata también que el sentido alegórico o las ambientaciones no contradicen el rigor histórico ni cuantas lecturas realizamos ahora con afán contextualizador. En ese Miranda culto e intérprete de recursos figurativos tan diversos se descubre una de sus contribuciones a la plástica local, ya que, salvo ejemplos puntuales, dicha dinámica no fue generalizada entre los maestros isleños durante el Antiguo Régimen. La Alegoría de Felipe IV como columna de la fe (colección particular, La Orotava) que le atribuimos en anteriores estudios sirve para percatarnos de dicha idea, pues en ella aflora una interpretación simbólica e iconográfica que asocia al autor con realizaciones del mundo virreinal. No solo cambia y reinterpreta el tema, sino que, incluso, resignifica planteamientos que estuvieron vinculados a la figuración de Carlos II como defensor de la Eucaristía ${ }^{33}$.

Ejemplo claro de otra propuesta de análisis para las creaciones religiosas es un lienzo que representa el martirio de santa Catalina y que el maestro pudo pintar para Catalina Prieto del Hoyo (1747-1822) durante la década de 1780, donde no faltan detalles inusuales a la hora de contextualizar la escena y hacer comprensible el tema abordado [fig. 4]. La suciedad del cuadro no ayuda a una valoración adecuada en estos momentos, pero en él, además de las concesiones al fondo y al discurso narrativo, advertimos detalles interesantes como el sentido alegórico, alusiones veladas al martirio por ser testimonio de salvación, el ornato escultórico en lo relativo al estrado del emperador Majencio o la colocación de algunos personajes en los extremos, recursos que podrían tener su origen en estampas de las centurias precedentes que el artista versionó a menudo.

El sentido de esta obra es inusual, porque, si validamos la tradición que transmiten sus depositarios, respondería a un encargo formulado por Catalina Prieto para que colgara en las haciendas que reedificó de El Malpaís y El Esparra-

32 Muñız Muñoz, Ángel (2008): «El grabado europeo y el Museo de Bellas Artes de Santa Cruz de Tenerife», El grabado y el museo. Santa Cruz de Tenerife, Ayuntamiento de Santa Cruz de Tenerife, pp. 39-41; López Plasencia, José Cesáreo (2014): «La Inmaculada Concepción con el Niño Jesús y España. Simbología, fuentes literarias e iconográficas de un lienzo de Juan de Miranda (1723-1805)», Boletín del Museo e Instituto Camón Aznar, 112, pp. 71-116; Lorenzo Lima, Juan Alejandro (2016): «El retrato en la producción pictórica de Juan de Miranda. Artificio e imagen para la sociedad canaria del siglo XviII", Anuario de Estudios Atlánticos, 62, pp. 24-28.

33 Para comprender los aportes de esta obra, incluida en AA. VV. (2018): Vecinos de la ciudad. Retratos en San Cristóbal de La Laguna (siglos XVI-XIX) [catálogo de la exposición homónima]. La Laguna, Gobierno de Canarias, p. 32, es conveniente la lectura de Pascual Chenel, Álvaro (2013): «Fiesta sacra y poder político: la iconografía de los Austrias como defensores de la Eucaristía y la Inmaculada en Hispanoamérica», Hipogrifo, 1, pp. 57-86. 


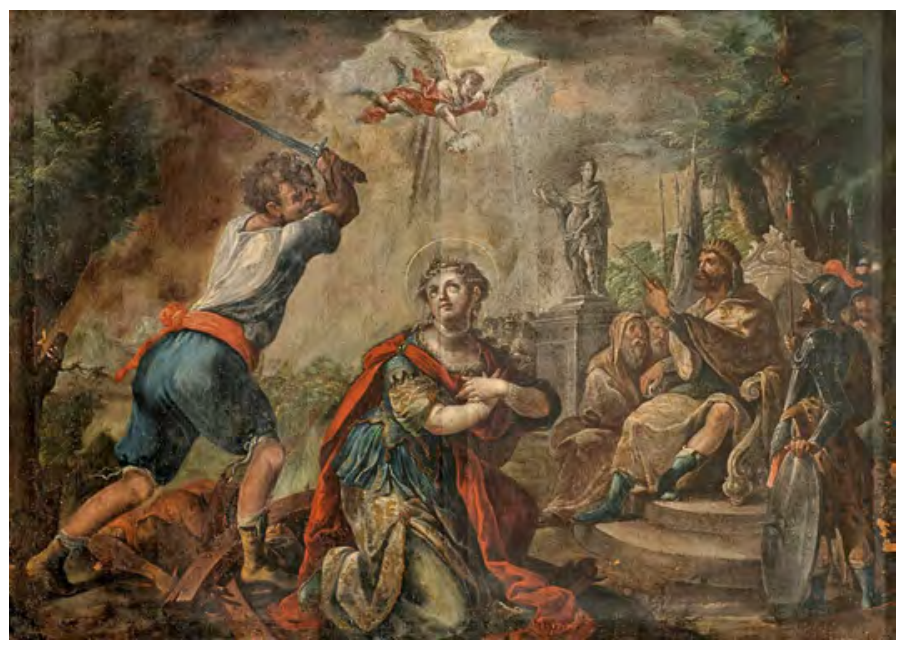

Fig. 4. Atribuido a Juan de Miranda: Martirio de santa Catalina. Colección particular, Garachico. [Foto: Efraín Pintos].

$\mathrm{gal}^{34}$. Sabíamos ya que dicha dama invocó a santa Catalina como "patrona y abogada ante todos los males que acechan a mis casas», por lo que este lienzo de formato rectangular le ayudaba a rememorar su martirio con un sentido claro. Tras él subyace el recuerdo en clave histórica, al modo que describían los devocionarios modernos o la literatura piadosa que empezó a escribirse y reimprimirse durante el siglo XviII. Su relato no esconde la idea común del martirio como prefiguración del exemplum virtutis, pero cuanto rodea a la misma santa que viste atuendo distintivo o de gala, común en el diseño a lo recreado por autores contemporáneos, previene acerca del origen dieciochesco que delatan otros componentes de una escena compleja por su afán narrativo ${ }^{35}$.

Circunstancias como las descritas en torno a Catalina de Ponte y su cuadro de santa Catalina animan a mirar y a remirar la producción de Miranda, a volver sobre ella y a descubrir a través de sus obras significativas nuevas propuestas de análisis. Conviene no quedarse en lo particular y promover estudios más genéricos, ya que, precisamente, otra de las contribuciones de Miranda fue definir un tipo de imagen que guarda relación con los modismos del llamado ahora catolicismo de las

${ }^{34} \mathrm{El}$ inventario de bienes redactado en 1824 informa que decoraba entonces una de las salas de la hacienda de El Malpaís. Archivo Histórico Provincial de Santa Cruz de Tenerife (AHPT): Archivo Brier Ponte. Caja 12, documento 24.

35 Lorenzo Lima, Juan Alejandro (2014): «A propósito de Juan de Miranda y el retrato del siglo Xvin en Canarias. Nuevas atribuciones, nuevas ideas", Homenaje a la profesora Constanza Negrín Delgado. La Laguna, Instituto de Estudios Canarios, pp. 399-401. 


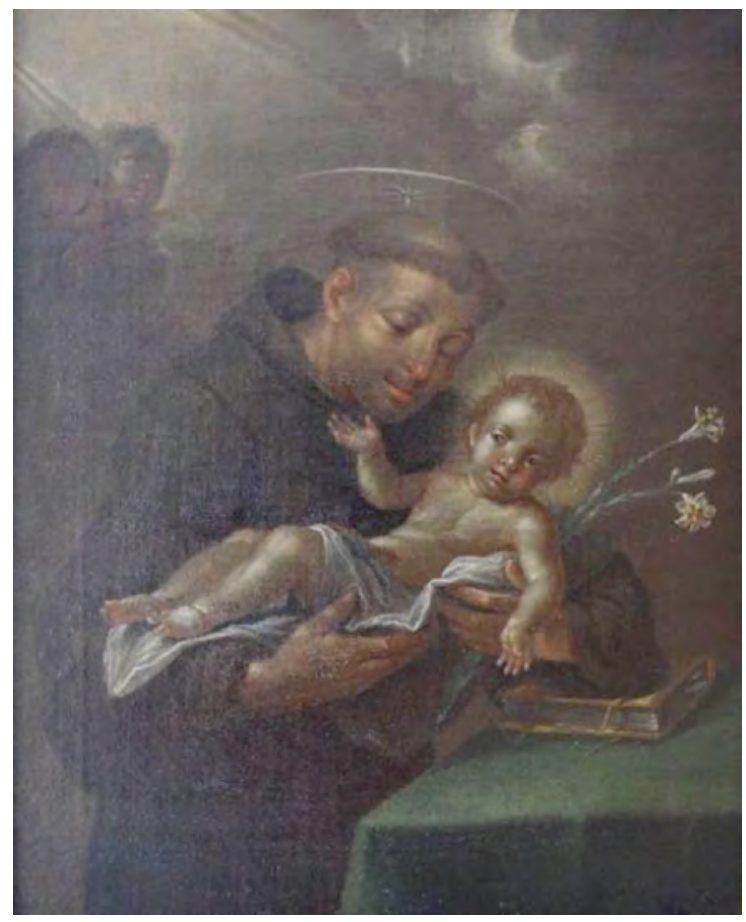

Fig. 5. Atribuido a Juan de Miranda: San Antonio de Padua. Colección particular, La Laguna. [Foto: Juan Alejandro Lorenzo].

Luces o reformismo ilustrado. A él, como ya hemos tratado ampliamente, se debió su tipificación y difusión en las Islas bajo planteamientos inusuales entre los maestros coetáneos ${ }^{36}$. Un testimonio bastante aleccionador de esa propuesta es el San Antonio de Padua que los herederos de Fernando Ascanio y Montemayor siguen conservando en La Laguna, no reproducido hasta ahora ni divulgado como merece, aunque ya formaba parte del catálogo mirandesco [fig. 5]. Su atribución se debe a Hernández Perera, quien pudo catalogarlo y exponerlo tras la restauración que Julio Moisés le practicó en $1967^{37}$.

Al margen de las concesiones dadas al tema, la simpleza que revela no es ajena a una reinterpretación de modelos populares y muy diversos, que abarcan desde la escultura devocional del siglo XVIII hasta la estampa coetánea de la Ilustración.

${ }^{36}$ Lorenzo Lima, Juan Alejandro (2014): Juan de Miranda..., op. cit., pp. 113-131.

37 Hernández Perera, Jesús: Restauraciones en Tenerife 1968 [catálogo de la exposición homónima]. Santa Cruz de Tenerife, Cabildo de Tenerife, 1968, n. ${ }^{\circ} 25$. También lo estudia RodríGuez GonZÁlez, Margarita (1986): La pintura..., op. cit., pp. 346-347. 
Por eso mismo, cualidades distintivas como los celajes de gamas grisáceas y azules, las cabezas de ángeles, el lenguaje gestual o el sentido mismo de las composiciones dando un protagonismo extremo a los atributos iconográficos tienen mucho que ver con el arte de aquel tiempo. De ahí que, puestos a especular sobre los motivos que posibilitaron este tipo de efigies devotas, no descartemos la acción de quienes alentaron una forma de religiosidad nueva por su afán de simplificar las figuraciones religiosas, despojarlas del misterio que las rodeaba y hacerlas distintivas de lo que acabaría tipificándose como buen gusto o gusto moderno.

Este fenómeno de cambio no se limitaba a las imágenes destinadas al culto público, sino que, incluso, acabó redefiniendo el sentido pío en los ámbitos domésticos. Ello explica también que gran parte de las pinturas de Miranda fuera destinada a la intimidad del hogar o a recintos de titularidad privada, donde muchas siguen preservándose en nuestro tiempo. Además, esa adecuación posibilitó que algunos lienzos variaran en lo relativo a formatos, técnica e iconografía, aunque la reiteración de temas y composiciones fue común por el uso de las mismas fuentes o láminas a la hora de darles forma. En ese sentido, una pintura hasta ahora inédita de la Adoración de los Magos que exhibe el retablo de la ermita de El Guincho, en Garachico, es pieza de interés y guardaría relación con otros encargos promovidos por Catalina Prieto del Hoyo. No debe olvidarse que durante la década de 1780 dicha dama reconstruyó la hacienda aledaña de El Malpaís y que desde entonces colgaron en ella cuadros atribuidos al maestro, esencialmente el Martirio de santa Catalina que tratamos antes [fig. 4] y un retrato suyo junto a otro de Melchor de Ponte y Prieto (1771-1817), su hijo y heredero frustrado ${ }^{38}$.

El modo en que el lienzo está sujeto al retablo, por medio de un claveteado burdo y tal vez de reciente añadido, deja entrever que pudo reutilizarse o colocarse allí de nuevo. La temática, el emplazamiento y el sentido piadoso que adquiere lo vinculan de forma directa con la casa de Ponte, puesto que los nombres de Melchor, Gaspar y Baltasar eran impuestos a sus miembros con frecuencia y la fiesta de la Epifanía cada 6 de enero contó con arraigo en el seno familiar. Las misas celebradas en ese recinto de su propiedad no eludieron tal coyuntura, sino que, al contrario, insistían en el apego que tuvo siempre un pasaje tan querido del ciclo navideño ${ }^{39}$. Al margen de dichas cuestiones, la existencia de esta pieza nos ayuda a comprender la génesis de las obras de Miranda y la relación tantas veces señalada con el grabado, tema recurrente a la hora de analizar su producción ${ }^{40}$.

38 LoRenzo Lima, Juan Alejandro (2014): «A propósito...», art. cit., pp. 387-411. Últimas valoraciones sobre los retratos, asociándolos oportunamente con la emblemática, en MuÑız MuÑoz, Ángel (2018): «El retrato de Catalina Prieto del Hoyo. Una alegoría de amor maternal», Vecinos de la ciudad..., op. cit., pp. 78-79.

39 Velázquez Ramos, Cirilo (2020): El ciclo de la Navidad en Garachico. Garachico, Ayuntamiento de Garachico, en prensa.

40 Muñız Muñoz, Ángel (2002): «Originalidad y copia. Modelos grabados en la obra del pintor Juan de Miranda», Revista de Historia Canaria, 184, pp. 241-253. 


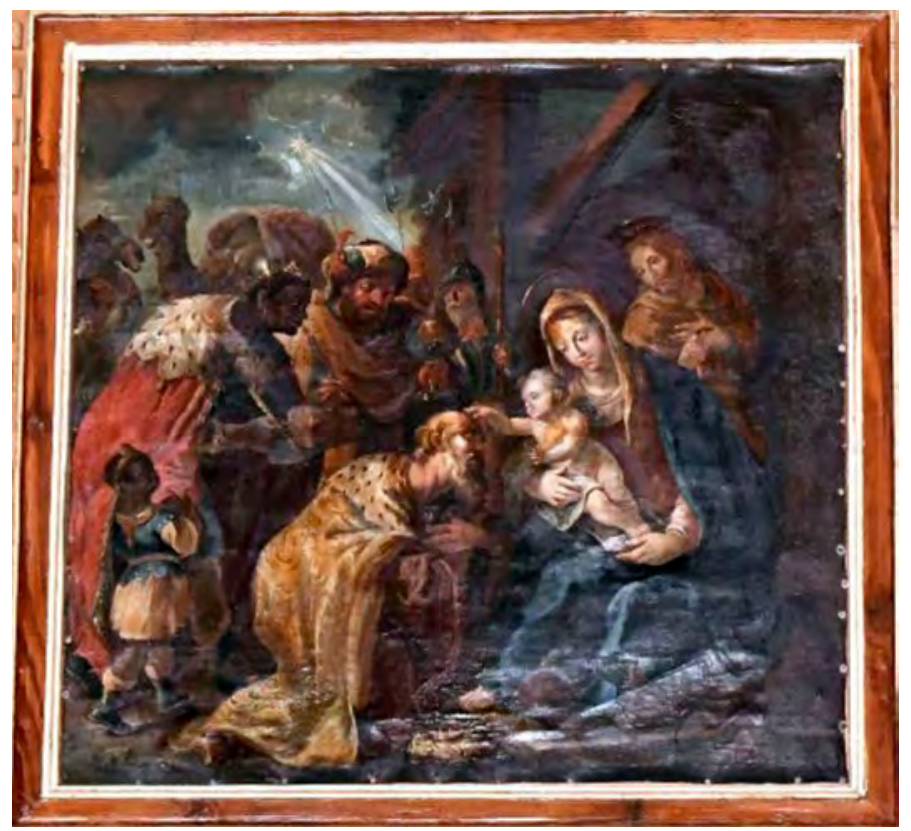

Fig. 6. Aquí atribuido a Juan de Miranda: Adoración de los Magos. Ermita de la Consolación, El Guincho (Garachico). [Foto: Miguel Velázquez Armas].

El estado actual de la pintura y la colocación a gran altura impiden estudiarla con una garantía plena, pero la atribución queda fundamentada en sus cualidades formales y el vínculo con otras piezas del mismo tema que se han adscrito al artista: esencialmente las conservadas en colecciones particulares de Las Palmas de Gran Canaria, Santa Cruz de Tenerife y Burgos, de las que nos ocupamos en un apartado previo. Como ya sabemos, todas comparten un mismo esquema compositivo, tendente a disponer el elemento central de la escena con los personajes de la Virgen y el Niño a un lado, reservando gran parte del lienzo para describir la comitiva de los magos. En ella figuran los tres reyes, al menos dos pajes y los camellos al fondo, quedando los últimos algo desdibujados por su mayor indefinición en lo técnico. Al lado opuesto, y siempre en segundo término, encontramos la representación común de san José, que cobija un fondo de arquitectura rudimentaria como alusión al pesebre [fig. 6].

La composición tiene su origen en grabados de los siglos XVI y XVII que reprodujeron artistas anteriores a Miranda en Europa y América, si bien para esta versión de El Guincho resulta indudable la correspondencia con una lámina de Johan Sadeler (1550-1600) que divulga modelos de Martin de Vos (1532-1603) [fig. 7]. Esa estampa fue incluida en un impreso litúrgico que ganó popularidad en las Islas desde la centuria precedente, como lo demuestra, entre otras, la Adoración de los Magos que cuelga en la ermita de la Caridad de Tacoronte y que pudo pintar un 


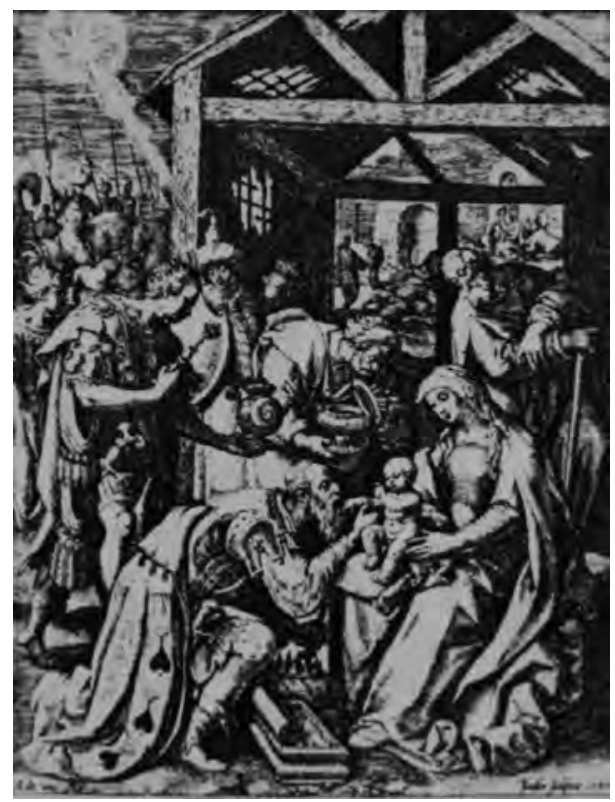

Fig. 7. Jean Sadeler: Adoración de los Magos.

[Foto: Jesús Pérez Morera].

maestro contemporáneo a Cristóbal Hernández de Quintana (1651-1725) ${ }^{41}$. Además, en colección particular de La Orotava localizamos un lienzo de formato medio y estilo posterior a dicho maestro que repite las mismas formas.

Miranda no hace una copia literal del grabado de Sadeler, aunque algunos detalles como la estrella del cielo y su resplandor sí están reproducidos fielmente. Por eso mismo, a diferencia de otras versiones recreadas en el lienzo a partir de dicho precedente, nuestro autor actualizó una propuesta formal que no encontraba tanta relación con la plástica coetánea. De ahí que, por ejemplo, colocara al fondo los camellos, simplificara el atuendo de los reyes, variara la colocación del Niño y suavizara los perfiles, dotando a la composición de un innegable espíritu dieciochesco. Esa cualidad aflora también en los rasgos de los personajes, y muy especialmente en los de la Virgen, que se prestan a una comparativa fácil con otras creaciones suyas que integran series iconográficas dedicadas a la infancia de Cristo ${ }^{42}$. Además, el colorido con predominio de grises, blancos y azules, matizados a menudo con rojos y amarillos, es rasgo distintivo del arte de dicho maestro durante la década de 1780 .

41 Pérez Morera, Jesús (1992): «Apuntes para un estudio de las fuentes iconográficas en la plástica canaria», Revista de Historia Canaria, 176, pp. 207-230.

42 Díaz Padrón, Matías (1966): «Seis pinturas...», art. cit., pp. 529-541. 
Lo que más llama la atención de ese hecho es la posibilidad que el artista tuvo de recrear a partir de precedentes tan heterogéneos, no realizando una copia fiel o tan fidedigna de ellos; y cuando ocurre lo contrario, no siempre, los elementos tomados de estampas antiguas se integran en una composición compleja y más elaborada, donde no se presentan como el motivo esencial ni el último referente de la escena a interpretar. Sirvan de ejemplo en ese sentido algunos personajes que incluye un cuadro grande y de ambientación confusa como la Expulsión de los mercaderes del Templo (Museo de Bellas Artes, Santa Cruz de Tenerife), cuyo modelo se encuentra en una lámina del mismo tema debida a Antoine Wierix (1555-1604) ${ }^{43}$. La manipulación de estampas por parte de Miranda es una práctica que Millares Torres advirtió ya en el siglo $\mathrm{xIX}^{44} \mathrm{y}$, cuanto más sabemos del tema, se acrecienta la idea de que el maestro reunió un elevado número de grabados y apuntes para definir sus obras. Ese hecho no es del todo novedoso, pero resulta de mayor atractivo si tenemos en cuenta la variedad de soluciones que mostraría una colección de láminas tan amplia como la que suponemos, la cronología cambiante de sus impresos y los muchos recursos que pudo ofrecerle antes de crear o abocetar sobre el papel. Se ha señalado ya que encontrar el punto de partida para algunas pinturas suyas no es fácil debido a los estudios o apuntes que pudo tomar a raíz del viaje desarrollado antes de $1773^{45}$, pero a veces esa dinámica no es tan clara y posibilita interpretaciones diversas.

A raíz de esta obra nueva de Garachico queda claro que la valía de Miranda como creador y recreador de imágenes radica en que supo aunar todo tipo de autores, referentes y motivos, puesto que hay testimonios de su relación con estampas firmadas por Wierix, Sadeler, Goltzius, Bolswert, Cort, Collaert y Saenredam, entre otros maestros flamencos de los siglos XVI y XVII. A ese repertorio previo se suman láminas estrictamente contemporáneas o debidas al buril de la Ilustración con artífices como Klauber, Cherau, Valls, Galcerán, Carmona, Fabregat y Ballester, cuyo conocimiento aclara la atención que académicos y eruditos depositaron en ellas ${ }^{46}$. Por eso mismo, los estudios formales y últimos hallazgos en este sentido demuestran que Juan de Miranda fue el artista canario del Antiguo Régimen que reunió un mayor número de modelos con el carácter que venimos señalando. Su

43 Pérez Morera, Jesús (1992): «Apuntes...», art. cit., p. 221; Muñız Muñoz, Ángel (2008): «El grabado europeo...», art. cit., pp. 39-41.

44 Millares Torres, Agustín (1982): «Juan de Miranda...», op. cit., p. 198.

${ }^{45}$ Rodríguez GonzÁlez, Margarita (1994): Juan de Miranda..., op. cit., p. pp. 27-28.

46 Rodríguez GonzÁlez, Margarita (1993): «Fuentes iconográficas en la obra de Juan de Miranda", IX Coloquio de Historia Canario-Americana. Las Palmas de Gran Canaria, Cabildo de Gran Canaria, t. II, pp. 1404-1412; MuÑIz Muñoz, Ángel (2002): «Originalidad y copia...», art. cit., pp. 241-253; Lorenzo Lima, Juan Alejandro (2014): Juan de Miranda..., op. cit., pp. 61-63, 76-77, 101-102, 134-153; Muñız Muñoz, Ángel (2013): «Grabados del siglo xviı en la obra de Juan de Miranda. A propósito de la Virgen de los Dolores y San Nicolás de Bari», Estudios Canarios. Anuario del Instituto de Estudios Canarios, LVII, pp. 145-156; Muñız MuÑoz, Ángel (2015): «La ilustración del libro como generador de modelos. Pintores canarios del Barroco y su relación con el grabado", Anuario de Estudios Atlánticos, 61, 19 pp. 
éxito radicó en la posibilidad que tuvo de integrarlos en temas complejos o resignificarlos para darles una novedad que no tenían, porque, al fin y al cabo, no hizo otra cosa que aunar recursos diversos con el propósito de aproximar sus formas a la cultura visual del siglo XVIII ${ }^{47}$.

\section{IMÁGENES COMO REFLEJO DEVOCIONAL DE UNA ÉPOCA: LOS SAGRADOS CORAZONES}

Un valor añadido que tienen las obras de Miranda es su estima en clave piadosa o devocional, entendiendo esa circunstancia como una prueba más de la adecuación al tiempo en que fueron realizadas. Antes señalábamos que muchas piezas de este tipo se prestan a una lectura múltiple por la unión de varios géneros e ideas, pero otras, no todas, sirven para contextualizar y aproximarnos al ambiente devocional que las posibilita. En ese sentido sorprende que la plástica mirandesca no se hubiera vinculado antes con el catolicismo de los ilustrados, cuyo afán reformista esconde una propuesta firme a la hora de renovar el culto y cuanto derivaba de él bajo normas o principios que omiten el componente popular. Lo que planteamos ahora es valorar su pintura con un sentido inverso, porque, precisamente, en ella pueden encontrarse las novedades que defendieron en Canarias personajes de relieve como José de Viera y Clavijo (1731-1813) y el obispo Antonio Tavira (1737$1807)^{48}$. En esa propuesta se advierte un aliciente que no ha sido explorado ni descrito lo suficiente, puesto que a buen seguro posibilitará lecturas que eluden el acabado o estudio formal. Nos enfrentamos a un contexto cambiante y de nuevos postulados estéticos donde, incluso, el arte de Miranda antecede a los planteamientos que años después Luján Pérez llevó al campo de la escultura por indicación de los mismos clérigos e intelectuales ${ }^{49}$.

Si nos limitamos a esa propuesta de análisis, el catálogo de un artista como Juan de Miranda resulta lógico y comprensible. Su vínculo con el reformismo borbónico explicaría, entre otras circunstancias, el predominio de temas comunes a muchos pintores de la Península como alegorías de signo político o representaciones aisladas y diferentes de la Inmaculada Concepción, cuyo patronato sobre España había alentado el rey Carlos III desde 1760. Sin embargo, no conviene quedarnos en ese aspecto como planteamiento genérico. En la producción del autor persiste un intento por aproximar sus lienzos al sentimiento latente y a unas devociones que empezaban a reinventarse o cambiar de modo imprevisible. Pensemos que, por ejemplo, el lienzo de san Marcial que pintaba en 1787 para la catedral de Santa Ana ayudó a

47 Sigue con ello una dinámica común y no interpretada bajo los planteamientos genéricos que defiende Mues OrTs, Paula (2017): «Estampas y modelos: copia, proceso y originalidad en el arte hispanoamericano y español del siglo XviıI", Libros de la Corte.es, 5, pp. 96-118.

${ }_{48}$ Lorenzo Lima, Juan Alejandro (2011): Juan de Miranda..., op. cit., pp. 113-131.

49 Cfr. AA. VV. (2007): Luján Pérez y su tiempo [catálogo de la exposición homónima]. Las Palmas de Gran Canaria, Gobierno de Canarias. 
definir un nuevo tipo de imagen religiosa bajo los auspicios de Viera ${ }^{50}$ o que sus efigies amables de santos, vírgenes y cristos sin demasiados signos de martirio llenaron un vacío que a veces tuvo continuidad en forma de serie ${ }^{51}$.

Es indudable que Miranda alentó en Canarias una narrativa pictórica nueva en torno a los personajes sagrados, cuyo planteamiento esencial era el mensaje cristocéntrico que alentaron teólogos y sacerdotes de signo reformista. De ahí que el autor contribuyese a resignificar con su pintura costumbres olvidadas como el rezo del vía crucis o, entre otras muchas, oraciones y prácticas cultuales que centraba la figura omnipresente de Jesucristo. Por eso mismo, a este personaje clave para el cristianismo racional y culto de la Ilustración dedicó grandes obras como las que decoraron el domicilio de la familia Carta en Santa Cruz de Tenerife (Entrada en Jerusalén y Expulsión del Templo, ahora en el Museo de Bellas Artes de dicha ciudad) o el cuadro de altar que presidió la ermita de la Magdalena en el pago de Conil (Arrepentimiento de Santa María Magdalena, exhibido en el Museo de Arte Sacro de Teguise), cuyos discursos plásticos no quedan tan lejos de lo recogido en sermones que Viera y sus contemporáneos predicaban a finales del siglo XvIII ${ }^{52}$.

La revalorización de Cristo como eje fundamental del nuevo catolicismo de las Luces es necesaria para comprender el sentido que tuvo una obra inédita del artista, que no dudamos en atribuirle ahora. Se trata de una efigie infrecuente y de calidad excepcional que representa al Sagrado Corazón de Jesús, conservada en un domicilio particular de La Orotava [fig. 8]. Su pertenencia desde antiguo a la casa de Ascanio refuerza la autoría propuesta de Miranda, ya que, gracias al relato de sus propietarios, deducimos que era parte de una colección donde se encontraban otras representaciones de san José y santo Domingo de Guzmán que se le adscribieron antes ${ }^{53}$. En este caso el interés es mayor porque forma pareja con una Dolorosa que muestra igual guarnición y tamaño de $48 \times 38 \mathrm{~cm}$, aunque la imagen mariana no revela tanta calidad en la resolución de algunos detalles como los ángeles del fondo, las manos de la Virgen, el ambiente celestial y ciertos componentes de los rasgos faciales. A nuestro juicio, ello invita a catalogarla como obra en la que intervino algún discípulo o artista de su círculo, siendo posiblemente una pieza abierta a la participación del taller [fig. 9].

La nueva efigie de Cristo es singular por cuestiones de fondo y forma, puesto que el contexto en que debió pintarse no era proclive a este tipo de figuraciones que

${ }^{50}$ Rodríguez González, Margarita (1994): Juan de Miranda..., op. cit., p. 55/n. ${ }^{\circ} 17$.

${ }^{51}$ Díaz Padrón, Matías (1966): «Seis pinturas...», art. cit., pp. 529-541; RodríGuez GonZÁLEz, Margarita (1994): Juan de Miranda..., op. cit., pp. 41-43/n. ${ }^{\circ} 3-5$.

52 Así lo planteamos en los comentarios de varias pinturas que ilustran el estudio de SánChez Rodríguez, Julio (2014): «Sermones de don José de Viera y Clavijo», Estudios sobe Viera. Religión. Familia. Iconografía. Emblemática. Las Palmas de Gran Canaria, Gaviño de Franchy Editores, pp. 81-251.

53 Rodríguez González, Margarita (2003): «San José con el Niño» y «Santo Domingo de Guzmán», Sacra memoria. Arte religioso en el Puerto de la Cruz [catálogo de la exposición homónima]. Puerto de la Cruz, Ayuntamiento de Puerto de la Cruz, pp. 74-75. 


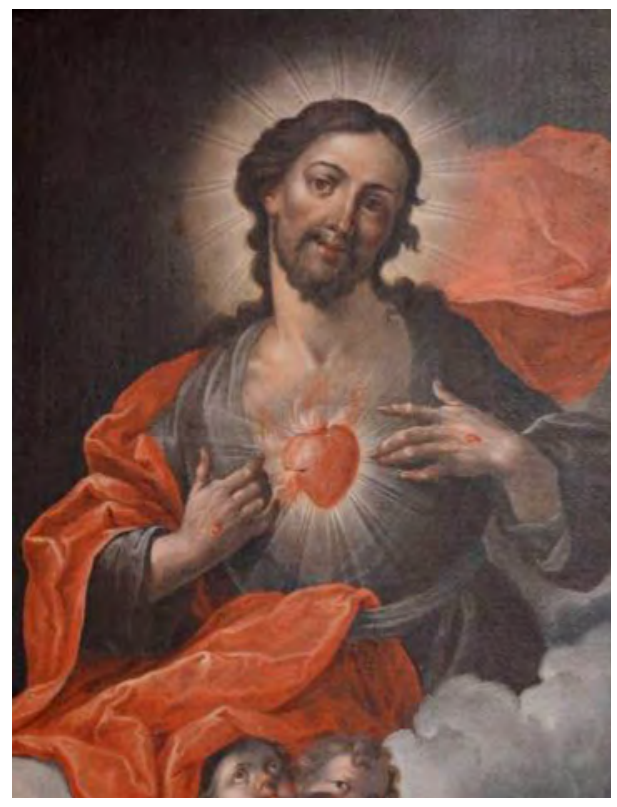

Fig. 8. Aquí atribuido a Juan de Miranda: Sagrado Corazón de Jesús. Colección particular, La Orotava. [Foto: Juan Alejandro Lorenzo].

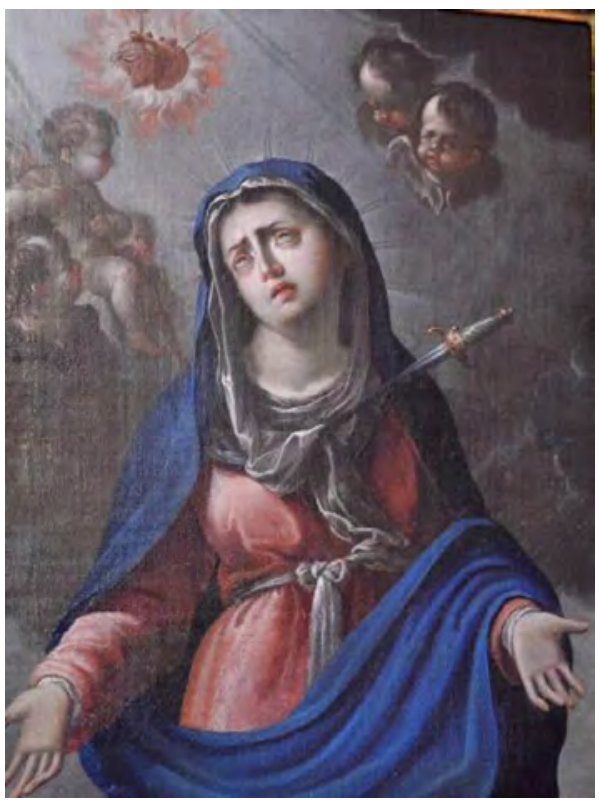

Fig. 9. Aquí atribuido al taller de Juan de Miranda: Virgen de los Dolores. Colección particular, La Orotava. [Foto: Juan Alejandro Lorenzo].

demandaba la piedad doméstica. Las representaciones del Corazón de Jesús se vincularon durante el siglo XVIII con los jesuitas y su expulsión del reino en 1767 no ayudó a que tuvieran continuidad en el medio isleño, donde tampoco fueron abundantes hasta las centurias siguientes ${ }^{54}$. Sin embargo, este lienzo que asociamos con Miranda cobra un protagonismo mayor por el hecho de que se encontrara desde entonces en La Orotava. A diferencia de lo sucedido en otras poblaciones del Archipiélago, en los monasterios de dicha localidad el culto al Sagrado Corazón ya tuvo éxito durante la década de 1740. Sabemos ahora que en 1742 las monjas clarisas costearon una misa por "quien dio la lámina del Corazón de Jesús:" ${ }^{55}$ años después el maestro Guillermo Veraud (...1710-1752) trabajaba en un relicario de madera para

54 Escribano Garrido, Julián (1987): Los jesuitas y Canarias 1566-1767. Granada, Universidad de Granada pp. 489-490. Para una aproximación a la iconografía contemporánea, no estudiada de un modo global, véase el trabajo compilador de Concepción Rodríguez, José (2018): «Anotaciones sobre el culto al Sagrado Corazón de Jesús en Canarias», Almogarén, 61, pp. 89-120.

55 AHPT: Delegación Provincial de Hacienda. Hacienda. Desamortización, 2960, f. 67v. 
su exhibición y procesión, no identificado hasta fecha reciente ${ }^{56}$. En 1792 la Inquisición ordenó retirar el altar que venía presidiendo dicha «lámina del Corazón de nuestro Señor" y una pintura de igual tema que colgaba en la iglesia de monjas catalinas, debido a su carácter herético en aquel momento ${ }^{57}$.

Suponemos que el lienzo conservado en la iglesia de San Nicolás era una figuración o retrato de Jesús y no solo del corazón con sentido alegórico, al modo de la que conservaba, entre otras, la parroquia del Realejo Bajo. Lo más probable es que imágenes de ese tipo tuvieran una amplia difusión gracias a la estampa en papel y los libros devocionales, de modo que en estas obras de uso cotidiano podría localizarse el antecedente de la creación de Miranda. Por eso mismo, al igual que muchas estampas del siglo XVIII que tienen un origen centroeuropeo, su efigie representa a Cristo de tres cuartos y señalando con las manos el corazón venoso, llameante y con estigma situado a la altura del pecho. Otros elementos llaman la atención de esta pintura, puesto que en sus facciones hay una tendencia mayor a la idealización de los rasgos fisonómicos. Se trata de la misma cualidad que siguieron maestros espańoles y americanos cuando representaban un tema tan controvertido ${ }^{58}$, por lo que tampoco extraña que procuraran mayor detenimiento al fondo con simulación celestial o al propio atuendo que integran una túnica de color grisáceo, la cinta de igual tejido que cińe la cintura y el manto rojo que se agita al fondo, tal vez para remarcar la sensación de profundidad respecto a los primeros planos.

La singularidad de esta efigie reside en las facciones con una carnación más clara que de costumbre, aunque, a pesar de la idealización manifiesta, pueden advertirse rasgos que lo vinculan con otras representaciones suyas del mismo Cristo o de san José. De igual modo, el apartado técnico manifiesta una sutileza mayor en la recreación de algunos componentes como los resplandores de la cabeza y el corazón, el cabello o las manos, cuyos dedos largos y estilizados revelan una indefinición hábil, propia de la madurez creativa del artista [fig. 10]. Atrás quedaron los tonos luminosos e intensos que caracterizan a la Virgen del Rosario procedente de Alicante (c. 1770), al Calvario o Cristo de Buen Paso que ganó tanta popularidad en Santa Cruz de Tenerife (1774) y, sobre todo, a los cuadros de gran formato que integran el políptico o retablo fingido en la parroquia de La Oliva (c. 1775).

56 Rodríguez Cabrera, Germán F. (2019): «El maestro Guillermo Beraud (Villa de Raffard, c. 1700-Realejo Bajo, 1752). Nuevas aportaciones sobre su vida y obra», Revista de Historia Canaria, 201, pp. 447-449.

${ }^{57}$ Archivo de El Museo Canario: Inquisición. Legajo xix/12. Cit. Hernández GonzÁLez, Manuel (2005): Los conventos de La Orotava. Santa Cruz de Tenerife, Ediciones Idea, p. 98.

58 Sirva de ejemplo lo sucedido con Luis Paret (1746-1789), quien asoció en ocasiones al Sagrado Corazón con la figura de Jesús Niño. En el contexto americano el fenómeno es semejante, tal y como estudia Kilroy-Ewbank, Lauren G. (2014): «Holy Organ or Unholy Idol? Forming a history of the Sacred Heart in New Spain", Colonial Latin American Review 23, n. ${ }^{\circ}$ 3, pp. 320-359. No obstante, para comprender y contextualizar los planteamientos que posibilitaron dicho proceder es oportuna la lectura de Escandell, Vicente R. (2009): Y mirarán al que traspasaron. La espiritualidad del Sagrado Corazón en los tiempos modernos (siglos XVI-XVIII) [tesis doctoral inédita]. Alicante, Universidad de Alicante. 


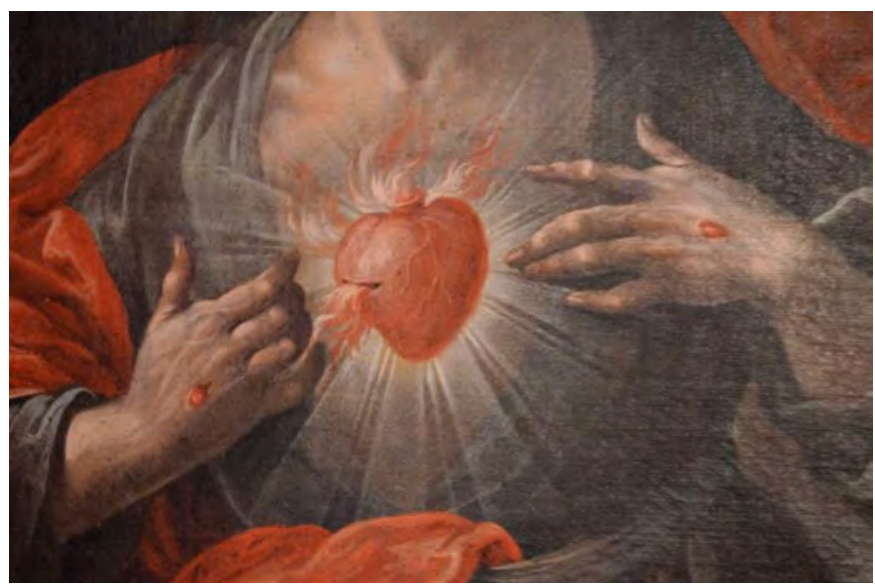

Fig. 10. Aquí atribuido a Juan de Miranda: Sagrado Corazón de Jesús. Colección particular, La Orotava. [Foto: Juan Alejandro Lorenzo].

A pesar de esas novedades y de las limitaciones que el tema presenta por su propia naturaleza, en el Sagrado Corazón advertimos otros detalles que guardan relación con la producción mirandesca. Los ángeles de la parte inferior, por ejemplo, remiten a los contemplados en efigies marianas y alguna versión de sus Inmaculadas, especialmente a los que el artista reproduce bajo una Virgen del Rosario donde copia modelos de Klauber (colección particular, Las Palmas de Gran Canaria) ${ }^{59}$. Además, el modo de componer las nubes en un lateral muestra mayor nivel de definición con tonos blancos, algo que no es habitual en representaciones suyas por el predominio de azules y grises con igual viveza. A diferencia de ellas, en esta obra la paleta se limita a una gama reducida de blancos, rojos y grises fríos, por lo que dicho cromatismo no es contrario al ideario mengsiano que defendían los académicos de aquel momento.

Esa originalidad de los valores formales guarda correspondencia con el estudio iconográfico, porque, como ya se ha señalado, los Sagrados Corazones no alcanzaron un desarrollo notable a lo largo del siglo XviII por las prohibiciones inquisitoriales y el rechazo que ganó la espiritualidad jesuítica. Pese a ello, en el catálogo de Miranda hay ciertas obras donde esos elementos tuvieron cabida al quedar vinculados con imágenes convencionales de la Dolorosa o la Soledad. Una de esas pinturas hace pareja con la efigie de Cristo que tratamos, puesto que en la parte superior su autor dispuso corazones alusivos a Jesús y a María gracias a los atributos iconográficos: puñal para uno y corazón de espinas con remate en forma de cruz para el

59 Rodríguez González, Margarita (1994): Juan de Miranda..., op. cit., p. 64/n. ${ }^{\circ}$ 26; Lorenzo Lima, Juan Alejandro (2011): Juan de Miranda..., op. cit., pp. 104-105. 
otro. Esta imagen de la Virgen describe un modelo que tuvo fama desde la centuria anterior y es deudor de grabados flamencos e italianos, aunque la ambientación procurada sí remite a modismos dieciochescos. En cambio, se advierte una destreza mayor en la recreación de los ángeles del lado izquierdo y los corazones que muestra al remate, quizá el aporte más significativo en ella [fig. 9].

Igual interés despierta una pintura del mismo tema y excelente factura que no ha tenido notoriedad hasta ahora ${ }^{60}$, si bien los documentos disponibles animan a estudiarla mejor. Se trata de la «lámina de los Dolores de Nuestra Señora» que cuelga desde 1785 en el aula capitular de la catedral de Santa Ana, cuyo encargo promovieron los miembros del cabildo eclesiástico un año antes. En sesión celebrada el 7 de septiembre de 1784 sus integrantes acordaron adquirir los enseres necesarios para el amueblamiento de dicha estancia, cuyas obras habían terminado semanas antes bajo la dirección de Diego Nicolás Eduardo (1733-1798). De ahí que el acuerdo plenario mencione explícitamente los azulejos pedidos a Valencia para el pavimento, una banquetería nueva, la colgadura que iba a confeccionarse en Las Palmas con tejido adquirido en La Orotava y el cuadro de la Virgen, citando expresamente que el último podría ajustarse también en Tenerife. Mientras tanto, ordenaron que no se colgaran otras pinturas en la sala a excepción de «una lámina [de la Dolorosa] sobre el armario, ínterin el expresado seńor Toledo encarga una nueva de la mano y [el] dibujo de la que tiene propia en su sala, que colocará a su tiempo con el adorno correspondiente» ${ }^{61}$.

Del apunte se deduce que el encargo de este cuadro, el primer trabajo notable de Miranda para la catedral y sus regentes, fue gestionado por el entonces canónigo Miguel Mariano de Toledo, quien contaba en su domicilio u oratorio con una realización suya. Lo más probable es que esa obra previa, no conservada o sin identificar ahora, representara también a la Virgen de los Dolores, puesto que fue la devoción principal de Toledo y de otros familiares hasta bien entrado el siglo XIx ${ }^{62}$. La pintura estuvo concluida meses después y, al igual que la colgadura de seda y el pavimento traído desde Valencia, pudo colocarse en la sala de reuniones a mediados de 1785. Su adquisición en Tenerife la tuteló el racionero Agustín Quevedo,

${ }^{60}$ No figura en el primer catálogo de Rodríguez González, Margarita (1986): La pintura..., op. cit., pp. 319-368, quien sí la recoge en el apartado «otras obras» años después. RodríGUEZ GonzÁlez, Margarita (1990): El pintor..., op. cit., p. 45. Es comentada y reproducida por HernáNdez Gutiérrez, A. Sebastián (coord.) (1999): La catedral de Santa Ana. Patrimonio Histórico. Las Palmas de Gran Canaria, Gobierno de Canarias, p. 98; y SÁnchez Rodríguez, Julio (2014): «Sermones...», op. cit., pp. 81-251.

${ }^{61}$ Archivo de la Catedral de Santa Ana, Las Palmas de Gran Canaria: Libro 52 de actas capitulares, s/f (cabildo de 7/9/1784). Cit. Cazorla León, Santiago (1992): Historia de la catedral de catedral de Canarias. Las Palmas de Gran Canaria, Real Sociedad Económica de Amigos del País, pp. 254-255.

62 Ello explica que en 1803 el mismo Toledo encargara a Luján Pérez la escultura que preside su capilla en la catedral, elogiada desde el siglo xiX como una de las mejores realizaciones de dicho artífice. Así lo recoge, entre otros, Martínez de Escobar, Bartolomé (1850): Memoria..., op. cit., pp. 14-15. 


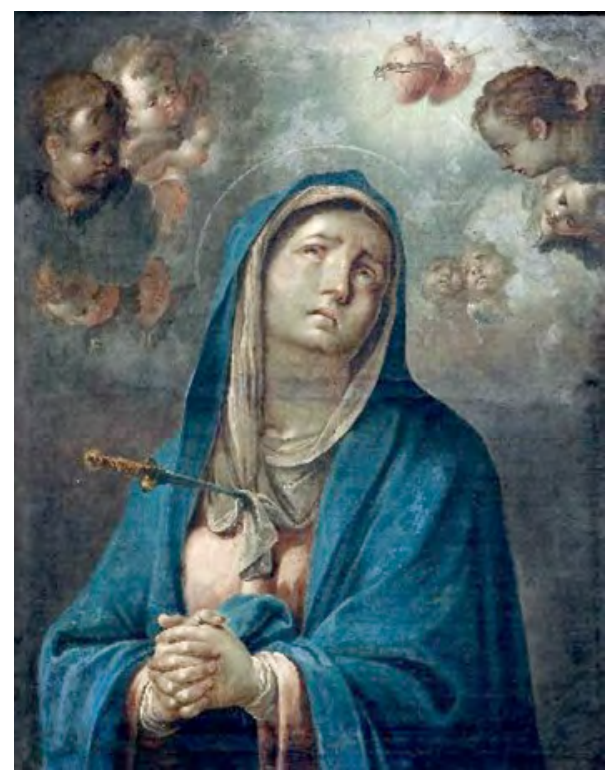

Fig. 11. Atribuido a Juan de Miranda: Virgen de los Dolores. Catedral de Santa Ana, Las Palmas de Gran Canaria. [Foto: Gaviño de Franchy Editores].

quien hizo entrega de los 20 pesos y seis reales de plata que tuvo de coste ${ }^{63}$. Lo más probable es que esa cantidad no incluya los gastos del marco o guarnición con talla ornamental de gusto rococó y el sobredorado posterior, acaso con diseño e intervención del artista.

$\mathrm{Al}$ margen de ese pormenor, lo interesante es que la pintura se convierte en un testimonio de las novedades que el arte de Miranda ofrecía en aquel momento, tendente a los débitos ya señalados con la estampa y a ambientar las obras con celajes en los que no faltan ángeles y atributos iconográficos. En este caso vuelven a aparecer una paleta fría y los Sagrados Corazones en lo alto, identificados de forma adecuada con el puñal y la corona de espinas [fig. 11]. Su calidad nos lleva a valorarla como un trabajo seguro del maestro y no como pieza donde participaron los discípulos que integraban su taller en Tenerife, cuyos aportes al catálogo mirandesco son difusos todavía. Ello explica la notoriedad del acabado y el protagonismo que dicho lienzo pudo ganar a la hora de difundir las cualidades del buen gusto entre los canónigos de Vegueta, puesto que la alusión al dibujo y a la buena mano de su autor previene sobre el éxito que Miranda tuvo luego como «notable en el arte de la pintura».

ReCibido: 7-5-2020; ACEPTADO: 11-6-2020

${ }^{63}$ Cazorla León, Santiago (1992): Historia de la catedral..., op. cit., p. 255. 